\title{
Cultural Heritage in Bangladesh
}

\section{Dr. Suman Barua}

\begin{abstract}
:
This, of course, does not necessarily change the view that the Magadha King, Bimbisara, was the first influential convert to the faith group, but might suggest a late-in-life conversion of the monarch who ruled over the Kingdom, based in Patna, close to where The Buddha is said to have found enlightenment beneath a banyan tree. It has long been suggested that, under Bimbisara's patronage, The Buddha was free to travel his realms, which are believed to have extended to, at least, the banks of the Old Brahmaputra River, half way across the lands that are now Bangladesh. The Emperor Ashoka, in the 4th century, famously, became a convert, too, and dedicated much of his later life to supporting propagation of the beliefs. His Empire, also based in Patna, probably spread even further eastward that Bimbisara's, reaching, possibly, deep into Arakanese territory. There are, unquestionably, at least three respects in which the history of Buddhism is inextricably linked with Bangladesh. The development and propagation required financial and human resources, not least in the construction of the substantial Vihara and temples that abound across the Buddhist world. At the archeological sites in Bengal were neglected for a long time due to geographical difficulty, access to remote locations from the main centers of the subcontinent, and mostly lack of government support. Since the independence of Bangladesh (1971) the government has undertaken a number of field projects including exacvations. This work is providing fresh evidence about the mostly Buddhist archeological sites, and new aspects of Bangladesh's cultural history. A year ago, tensions were on a razor's edge in southeast Bangladesh, as Muslim mobs looted and vandalised 19 Buddhist temples and monasteries. The government of the Muslimmajority nation renovated and reconstructed all the temples and monasteries, drawing praise from across the region.

It is noteworthy to mention that archeological researches in Bangladesh are asking the mention the government for increased budgetary allocations in order to preserve the important cultural heritage sites in this country. And with good reason- Bangladesh is somewhat of a forgotten repository of the South Asian Buddhist heritage, and it is high time that its sites are given the attention and care they deserve.
\end{abstract}

Key Words: Emperor Ashoka, Monastery, Cultural Heritage, Archeology, Bengal.

\section{Introduction:}

Civilization in Asia has been molded by Buddhism's outstanding contribution during more than the last 2500 years. Buddhism emerged as a World religion essentially of peace and humanism influencing the religious, social and cultural lives of the hundreds of millions of people in the vast Asian continent and the world at large. We can see now many records in history.

We know that the Ganges delta, especially, was a flourishing centre of manufacturing and trade since before the time of the Buddha, and the wealth generated there must have played 
a part in financing the development, whilst the trade routes through the delta will certainly have been the means of propagation. Propagation along the great trade routes that converged on the delta lands from across north India, from the lands of the Himalayas; from ancient China down the Brahmaputra River; from the countries of southeast Asia, and from Arabia and the countries of the Mediterranean. Buddhism became the first of such groups in the age of writing. Writing, especially the development of Sanskrit, so closely associated with both Hindu and Buddhist groups, certainly evolved in "north east India." We can probably be more definite in suggesting the development derived as much from commercial interests as from philosophical ones. Philosophy can be taught, verbally; business transaction requires recording. It seems probable, therefore, that writing developed into major centres of trade, of which the Ganges delta was certainly the largest east of the Mediterranean. The history and archaeology, of which Bangladesh, a largely Islamic nation, seems embarrassed. The Holy Prophet may have injuncted his followers, "Seek ye knowledge, even unto China," which, as the great Malaysian, Dr Mahatir, has pointed out clearly suggested knowledge for the sake of knowledge, but it is not, it seems, an injunction taken seriously in Bangladesh. The fact that not even comparative religions are taught in Bangladeshi schools will certainly prove a difficulty in delivering informed and educated services to such visitors. But this is not an insuperable difficulty. On-line research into the history of Buddhism reveals remarkable amounts of speculation, rather than fact, and often some contradictions. What, as a result of this Lumbini revelation, we can expect is a move to rewrite at least some of that history. And that may be a rare window of opportunity for the academic world of Bangladesh to stand by a real history of their lands, and ensure that the reality of Bangladesh as having had at least a significant role, but more probably a leading role, in nurturing and propagating this great faith group in its cradle here in the lands that are now Bangladesh.

This article is intended to provide the readers with a cursory glimpse into Buddhism and its impact on the ancient civilization of Bangladesh. Bangladesh, though a new country which achieved independence long ago is an ancient land in the eastern part of the South Asian SubContinent with more than 2000-year-old rich culture and civilization. The Bangladesh

National Cultural Commission formed by the Government of People's Republic of Bangladesh has depicted Buddhist civilization in ancient Bangladesh as having made an outstanding contribution to the national heritage of this country.

\section{Emperor Ashoka:}

Ashoka Maurya (304-232 BCE), commonly known as Ashoka and Ashoka the Great, was an Indian emperor of the Maurya Dynasty who ruled almost all of the Indian subcontinent from c. 268 to 232 BCE. One of India's greatest emperors, Ashoka reigned over a realm that stretched from theHindu Kush mountains in the west to Bengal in the East and covered the entire Indian subcontinent except parts of present-dayTamil Nadu and Kerala. The empire's capital was Pataliputra (in Magadha, present-day Bihar), with provincial capitals at Taxila and Ujjain.

\section{Monastery:}


The monastery is a building or complex of buildings comprising the domestic quarters and workplaces of monastics, whether monks or nuns, and whether living in communities or alone (hermits).

1350-1400; Middle English < Late Latin monastērium < Late Greekmonastếrion monk house, There was one monastery nearby, an ancient site more than 200 years old, but no tourists had ever stayed there. It was during these months that the Buddha would retire to some monastery and cease from travelling and teaching for a time.

\section{Cultural heritage:}

Cultural heritage is the legacy of physical artifacts and intangible attributes of a group or society that are inherited from past generations, maintained in the present and bestowed for the benefit of future generations. Cultural heritage includes tangible culture (such as buildings, monuments, landscapes, books, works of art, and artifacts), intangible culture (such as folklore, traditions, language, and knowledge), and natural heritage (including culturally significant landscapes, and biodiversity). Something that comes or belongs to one by reason of birth; an inherited lot or portion:

A heritage of poverty and suffering; a national heritage of honor, pride, and courage.

\section{Archaeology:}

Archaeology or archeology, is the study of human activity in the past, primarily through the recovery and analysis of the material cultureand environmental data that has been left behind by past human populations, which includes artifacts, architecture, biofacts (also known as ecofacts) and cultural landscapes (the archaeological record). Because archaeology employs a wide range of different procedures, it can be considered to be both a social science and a humanity, and in North America, it is thought of as a branch of anthropology, although in Europe, it is viewed as a discipline in its own right, or related to other disciplines. For example, much of archaeology in the United Kingdom is considered a part the study of history, while in France it is considered part of Geology.

\section{Bengal:}

Bengal is one of the most densely populated regions on Earth, with an estimated population of 250 million people and a population density exceeding 900 people persquare kilometre. Most of the Bengal region lies in the low-lying Ganges Delta, the world's largest river delta. In the southern part of the delta lies the Sundarbans the world's largest mangrove fores and home of the Bengal tiger. In the coastal southeast lies Cox's Bazar, the world's longest beach with a length of $120 \mathrm{~km}$ (75 mi). While most of region is rural and agrarian, it includes two megacities: Kolkata (formerl Calcutta) and Dhaka (formerly Dacca). Bengal (Bengali: Bangla/Banla) is a geographical and ethno-linguistic region in the eastern part of the Indian subcontinent, at the apex of the Bay of Bengal and dominated by the fertile Ganges delta.

\section{Buddhism in Bangladesh:}


Bangladesh was once the cradle of Buddhism still bears traces in the various

Architectural remains of temples and monasteries with large number of Buddha images, relics, copper and stone plates discovered at different times from various parts of the country. There is a difference of opinion among researchers as regards spread of Buddhism in Bangladesh. Much currency is given to the theory that the teaching of Buddha propagated during the lifetime of Buddha since he himself came to Bangladesh (Samatat) on a visit while preaching his new thoughts. Fa-Hien (5th Century), Hieun-Tsang (middle of the 7th Century), I Tsing (end of the 7th Century) and others in their travel accounts referred that Buddha came to PundraBardhan (northern Bangladesh) and preached his principles also at Samatat (south-eastern Bengal), presently Chittagong, Noakhali and Kamasbama (now Murshidabad, West Bengal). The Chinese travelers saw hundreds of monasteries and centers of Theravada and Mahayana Schools in these parts of Bangladesh and West Bengal of India. The description in ancient Buddhist literature like Angutta Nikaya, Samjukta Nikaya, Divyabadan, Asokabadan and Avadan Kalpalata also testify the truth of the above. The names of two prominent disciples of Buddha Bangisha and Bangantaputta show that they might have derived their names from Bangla (Bangladesh). The copper plates, stone inscription found at Mahasthangar (Bogra), Paharpur Somapuri (Jaipurhat), Mainamati (Comilla) and Ashrafpur (Dhaka) were dated between 6th and 10th Centuries.

The National Museum of Dhaka has a big hall reserved for Buddhist historical objects and contains unique sculptures in stone, metal and wood. The terracotta figures from Paharpur Monastery (Jaipurhat) arouse great popular interest. A few words can be added here on Bikrampur Bihar which is only a few miles away from Bikrampur, the oldest historically recorded city in the neighborhood of Dhaka. It was an important place during the hey-day of the Pal rulers of Bengal. According to some historians, the name Bikrampur is derived from the title Bikramaditya, said to have been assumed by Dharmapal Deb, the second and the greatest of the Pal dynasty who built a Buddhist monastery there. After the death of Buddha in 646/647 A.D. his empire fell to pieces and independent kings established themselves in Bengal. For some centuries, knowledge about East Bengal (Bangladesh) remains scanty after the death of Sasanka in 639 AD for about a Century from 650 A.D. to 750 A.D. But certain amount of information has been derived from inscribed copper plates. The object of the plates was to record their grant of land, but they are also of historical value. Preambles of these grants mention the king or chief in whose time the grant was made and record his ancestry. One local dynasty, that of the Khadgas are mentioned in a plate found in the Dhaka district at Ashrafpur. These kings were Buddhists and their capital was Karmanta, which N.K. Bhattsali, late Curator of the Dhaka Museum, identified with Kamta, fourteen miles west of Comilla. In the 10th and 11th Century there was another line of local ruler, also Buddhist by religion, who bear the name of Chandra and had their capital at Bikrampur in the Dhaka district. Knowledge of their existence is due to the discovery of copper plates grants at Idirpur and Kedarpur in this district, as well as Rampal, the old capital of Bikrampur in Dhaka. At any rate, there can be doubt about the fact that a portion or the district of Dhaka was included in the ancient kingdom of Bramhaputra valley of Kamrup. A passage in the Jogini Tantra distinctly states that the southern boundary of that kingdom was the junction of the river Bramhaputra and the Lakshya, where the town of Narayangonj is located today. The early traditions that have come 
down to speak that Dhaka and some of the neighboring districts were originally under the sway of Buddhist king. The numerous Bihars scattered all over the country were meant not only for monastic way of teaching but also for imparting lessons on subjects like arts, crafts, astronomy, geography, agriculture, herbal medicines, pottery and so on. Thousands of monks and students used to reside in these Bihars for equipping themselves with different skills and knowledge, in addition to their scriptural lessons.

According to O'malley, this Banga or Bangla was incorporated in the empire of Harsha. We have brief account of this part of the country from the pen of the Chinese pilgrim Hiuentsang, who traveled in different parts of India from 630-643 A.D. when Harsha was at the height of his power. According to his account, Samatat corresponded to the ancient Banga, a low-lying country bordering the sea, rich in corps, flowers and fruits. The climate was soft, the manner of the people was agreeable. The inhabitants were of small stature and of dark complexion but diligent in acquisition of learning. There were about thirty Buddhist monasteries with some 3000 priests and thirty Brahaminical temples. He also writes that it is interesting to observe that adherents of orthodox Hinduism, Buddhism and Jainism lived side by side apparently peacefully. This was Bangladesh depicted through the pen of HiuenTsang. Another version says that Samatat was the capital of South and East of Bengal before the 7th Century A.D. Chinese traveler Hiuen-Tsang recorded that Pundrabardhan, Samatat and Tamralipti were in a very flourishing state of condition. According to Tamra Sasana found at Ashrafpur (Dhaka), much information has come to light that Khadga dynasty ruled here. In pre-Muslim period the present Dhaka district was included in the administrative unit of Banga which at times used to be identified with Samatata and Harikel. Since Hiuen-Tsang noticed Ashoka stupas in Samatata, Mayurya rule in the district cannot be denied. Ruins of stupas built by Ashoka in the village Dhamrai (Dhaka) still stands as a witness of flourishing state of Buddhism. Dhamrai is supposed to have derived its name from Dharmarajik. This view was corroborated by the historian Jatindra Nath Bose. The nomenclature itself has a significant background. Savar, not far from Dhaka was visited by Buddha according to Buddhist literature and was confirmed by the Bangalee historian J.N. Bose. It has monument created by king Ashok. In course of time the place has been known as Dharmarajika which again turned into Dharmarajika. Like the ruins in Dhaka district bearing the traces of rich Buddhist culture another district Dinajpur (northern part of Bangladesh) also bears evidence of Buddhism, highly patronized by the ruler themselves. The Pal Rajas were princes of Gaur, a name which seems to have applied rather to the whole province, of which Dinajpur formed the principal part. The founder of this dynasty appears to have come from Western India and had become Buddhist. Francis Buchanan (Hamilton) while describing of education in the district of Dinajpur in the beginning the sate of 19th Century still found the traces of Buddhism there. He wrote, The only vocabulary used in Dinajpur is the Omarkosh or

Omorsinghe, whom the scholars as usual considers a person belonging to the sect of Buddha. Since Buddhism flourished there in the court of Bikram. Buddhism has traveled a long way under the patronage of series of ruling dynasties. Chandra (7th Century), Pal (8th to 11th Century), Deb (9th to $13^{\text {th }}$ Century) and the Barman (11th to 12th Century). These dynasties 
patronized Buddhism successively for nearly seven hundred years when Buddhism, specially its Mahayana sect, found a golden era in Bangladesh. Bangladesh has produced a large number of Buddhist scholars who were not only known for disseminating religious doctrines and ideology as teachers of different Bihars but also contributed to the development of creative art. These glorious sons of ancient Bangladesh like Santarakshit, a professor of Nalanda University; Atish Dipankar Srijnan, world famous saint and philosopher; Pandit Shilabhadra, the Principal of Nalanda University; Pandit Prajnabhadra alias "Tilopa ", the Principal of Pandit Bihar University and other scholars made many contribution to the progress of mankind. The Siddhacharyas (saint scholars) of ancient Bangla like Luipa, Kanupa, Ariyapa or Haripa who were engaged in teaching in Bihars used to compose mystical lyrics or songs known as Charyapadas which marked the creation of Bengali language more than one thousand years ago.

In Eastern India (presently Bangladesh) Buddhism and its art under the Pals and Sens (A.D. 730-1197) gradually assimilated with Shibism and Baisnavism. The last great center of Buddhism in the Sub-continent was at Nalanda in Bihar (India). Later, Buddhism gradually began to assimilate with Hinduism in India and almost disappeared with the advent of Muslim era.

Travelers and tourists from Indian Sub-continent and Bangla walked thousand of miles and even crossed the mighty Himalaya with the message of love and compassion. The best example is provided by the renowned Buddhist saint-scholar Atish Dipankar Srijnan who more than 1500 years after Buddha, preached his teachings beyond India. About Atish there are many verses found in local Bangla literature as follows:

\author{
'He crossed the mountain Covered \\ with perilous frost: \\ $\mathrm{He}$ is the Atish of Bangla who lit the \\ light of learning in Tibbat'.
}

After the 12th Century, Buddhism was challenged by militant Brahmanism and other opposing forces in the Sub-continent wiped out from its birth place. Lama Taranath however, added that the reason of the decline of Buddhism emerged from within the creed itself. "Buddhism in its latest phase, as Taranath vividly described it, almost completely surrounded precisely to those beliefs and practices, a direct rejection of which the Buddha himself had preached in his original creed. For all we know, it was a creed concerned above all with the fact of suffering and with the way out of suffering.

\title{
The Buddhist Community of Bangladesh - A Brief Survey:
}

The mid-19th Century was a turning point in the religious history of the Buddhists of Chittagong which in fact was the home of Buddhism in the then Bengal and undivided India. In that very dark age, the Buddhists were steeped in deep superstitions. The Sangharaj of neighboring Arakan most Venerable Saramedha Mahathero came on a chance to visit Chittagong in 1856. He was shocked to see the condition of Buddhism with Tantric rituals and worship of false gods and goddesses. The Sangharaja Sramedha again visited Chittagong and 
Chittagong Hill Tracts in 1864 and took upon himself the task of reforming the prevailing Buddhism in accordance with Dhamma and Binaya of the Tripitaka. He faced a tough time but he succeeded in having the support of Rani Kalaindi, the ruler of the Chakma dynasty of the Chittagong Hill Tracts and some leading figures in Chittagong during his Theravada reformation movement. As a result, more than 95 per cent of total number of Buddhist monks in Chittagong, Chittagong Hill Tracts and other Buddhist-populated regions came under the fold of the newly reformed Theravada Buddhist Sangha.

The Buddhist community during the days of British rule sought to assert social, religious and cultural existence. One important event was the holding of a big Buddhist Conference in 1938 in Hoara para (suburb) village of Chittagong on the occasion of birth anniversary of

Most Venerable Aggasara Mahathero who was an eminent religious personality. During the British rule the Buddhists called for a separate identity for themselves as a religious community. Two Buddhist leaders - Dr. Arbinda Barua, Barister-at-Law and Rai Bahadur Dhirendra Lal Barua were nominated members of Bengal Legislative Assembly in Calcutta in the Forties to represent the cause of the Buddhists. In 1947 at the time of independence from the British rule, the Indian Sub-continent was partitioned into India and Pakistan. Buddhist populated regions like Chittagong and Chittagong Hill Tracts were included in

Pakistan. The Buddhists identified themselves with the new State. Most Venerable Visuddhananda Mahathero has been President since 1950 till now of the Sangha, now named Bangladesh Bouddha Kristi Prachar Sangha. During the Pakistan period the first Buddhist Monastery in the capital city was established in Dhaka for which the government had made a gift of five acres of plot of land for the entire Buddhist community. A very dynamic and talented social worker with sharp intellect, Deva Priya Barua, popularly known as D.P. Barua infused a new direction in the Bouddha Kristi Prachar Sangha of which he was the Secretary General for 16 consecutive years from 1961 to 1977 while Most Venerable Visuddhananda Mahathero and later Most Venerable Joytipal Mahathero had been the President. During the Sixties D.P. Barua made outstanding contribution in the emergence of the Sangha with its national and international identity as well as socio-cultural activities of the Buddhist community including establishment of the Monastery in Dhaka known as Dhammarajika Bihar. Two other temples in the capital city recently established are International Buddhist Monastery founded by the Most Venerable Santapada Mahathero, former President of ABCP and Secretary General of Sangharaj Bhikkhu Sangha and Sakyamuni Bihar established by the Buddhists of Chittagong Hill Tracts living in Dhaka.

During the war of liberation of Bangladesh in 1971, Ven. Joytipal Mahathero together with Ven. Santapada Mahathero and some others made significant contribution in mobilizing world opinion in favor of Bangladesh struggle for independence in a crucial phase of our national existence. Ven. Joytipal visited Sri Lanka, Thailand and Japan in August 1971 to mobilise Buddhist public opinion in favor of Bangladesh struggle.

\section{Wari-Bateshwar:}


Recently important discoveries were made during a small-scale excavation at Wari. WariBateshwar a significant archaeological site in Bangladesh. Banglapedia refers, Located three kilometres west of Belabo Thana of Narshingdi district, Wari (Wari) and Bateshwar (Bateshvar) are two contiguous villages long known for being the find-spot of silver punchmarked coins in Bengal. The villages are situated on the Pleistocene flat surface of the eastern Madhupur tract. A small dried-up river, called Kayra, flows in an east west direction on the northern side of the villages. The landscape of the area suggests that during an early historic period the old Brahmaputra river used to flow near the village. The river has now shifted a few kilometres eastward. The Meghna flows only a few kms to the south of this area and the Arial Khan flows into it. The location of the two villages on a comparatively high, floodfree ground; their proximity to the old Brahmaputra, and access to the Meghna add significance to the site. Md Hanif Pathan, a schoolteacher, first brought the archaeological importance of the villages to light in 1933. Later his son Md Habibullah Pathan, an amateur archaeologist took initiative to collect antiquities and study them. Sporadic explorations had revealed that the major part of Wari and Bateshwar villages was occupied in the ancient period. Signs of ancient settlements are noticed in the surrounding villages namely, Raingertek, Sonarutala, Kandua, Monjal, Chandipara, Patuli, Jaymangal, Harisangan, Jessore, Kundapara, Gotashia, and Abdullanagar. Hundreds and thousands of semi-precious stone beads, glass beads, Iron artifacts, silver punch-marked coins and many minor artifacts have been reported from the region from time to time. Unfortunately, all the artifacts were chance finds. They came out during ploughing of fields, digging ponds and other domestic activities and during rainy season when rainwater washes away the topsoil. Among the discoveries a sherd of Rouletted Ware, a piece of Knobbed Ware, a good number of Northern Black Polish Ware, Black-slipped Ware, common ceramics, a few semi-precious stone beads, chips, flakes and cores of semi-precious stone beads, melted pieces of iron, sign of fallen mud-wall and signs of some sort of burning activity are very significant. The discovery of tiny parts like chips and flakes of semi-precious stones clearly prove the existence of semi-precious stone bead manufacturing centre at Wari. The flakes are produced out of primary chipping or dressing cores. The exotic beads at Wari-Bateshwar region are objects of a bye-gone art and bear silent but eloquent testimony to the marvelous artistic skill attained by the Wari-Bateshwar people. The raw materials are not available within present Bangladesh, possibly it had to be collected from outside.

A part of fallen mud-wall has been found in NBPW level. The discovery is very significant because it reveals the long tradition of mud-wall architecture in the region in particular and in Bengal in general. This mud-wall is possibly the earliest evidence of architecture in Bangladesh. However, brick structures (brick size, $32 \times 30 \times 6 \mathrm{~cm}$ ) are also found in the region. The religious nature of Wari-Bateshwar habitation is not very clear. The discovery of a Knobbed Ware at Wari hints at the existence of Buddhist practice in the region.

It has been inferred that Wani-Bateshwar was the eastern most limit of the Mauryan Empire. The recent discovery of NBPW from excavation has provided positive support in favour of this hypothesis. It has been argued by scholars that the wide distribution of NBPW is concomitant with Mauryan imperialism. The discovery of NBPW is significant for the understanding of Buddhism and trade routes also. 
The excavation has placed Wari-Bateshwar in the early historic period. The $\mathrm{C} 14$ dates have pushed back the chronology of Wari to 450 BC. The Northern Black Polished Ware, Rouletted Ware and Knobbed Ware are chronology markers of the Early Historic period. The numerous NBPW sites of the Subcontinent are placed between circa 700 to $100 \mathrm{BC}$ or $50 \mathrm{AD}$, Rouletted Wares to circa 3rd century $B C$ to 2 nd century $A D$ and Knobbed Ware to 2 nd century $B C$ to 2 nd century AD.

\section{Paharpur Buddhist Monastery (Sompura Mahavihara)}

The monument at Paharpur was first excavated in 1922-23 and it is considered the largest monastery in the Indian sub-continent. It is known as the Sompura Mahavihara, located in Rajshahi district. The excavation continued until 1934 and a report was published in 1938 as "Memories No. 55 of the Archaeological Survey of India". The origin dates to the Pala Dynasty in 8th century. The site covers an area of 27 acres of land that includes a quadrangular court measuring more than 900 feet.

\section{Maninamati Shalban Vihara}

At Mainamati the principle monument is the Shalban Vihara which is the main interest here. During Mr. Nalini Kanta Bhattasali's tour, he found several Buddhist sites including Shalban Vihara and reported his findings in his book. ${ }^{1} \mathrm{It}$ is mentioned that about 55 scattered ancient remains of settlements from the 8th - 12th century AD known as Mainamati Lalmai are located throughout the Comilla district.

\section{Bhasu Vihara}

During Cunningham's tour, he identified this site six kilometers north-west of Mahasthangarh. Excavations have exposed two large Buddhist monasteries and a mediumsized Buddhist shrine. In 1970-80s further excavations revealed a small monastery consisting of 37 small rooms. From the Bhasu Vihara site, bronze statues and terra-cotta plaques have been found. The buildings indicate three types of religious architecture (monasteries, shrine and cruciform structure) as mentioned by Monica L. Smith. ${ }^{2}$

\section{Buddhist Vihara in Bikrampur}

The excavation on the Buddhist Vihara in Bikrampur of the Dhaka district was jointly conducted by the Department of Archaeology of Jahangirnagar University and the Agrasar Bikrampur Foundation. After four years' effort a Buddhist monastery was completely unearthed by March 2013. More than 100 statues and sculptures have been found in the monastery site.

\section{Conclusion:}

\footnotetext{
${ }^{1}$ Iconography of Buddhist and Brahmanical Sculptures in the Dacca Museum (1929).

2 The Social Construction of Ancient Cities-2003.
} 
What a prospect, for a Muslim academic in Bangladesh to undertake the work required to assist in rewriting a history of Buddhism! Opportunities like this, to reopen received wisdoms, are rare in the heritage world, but when they open, they can be more easily seized, and used to reflect previously ignored and unpublicised realities. If only tourism and culture in Bangladesh were as closely linked in management, and practice, as they need to be to realise the opportunities that stand at the door of the country.

\section{References:}

Ancient Bangladesh- A Study of the Archaeological Sources with an Update on Bangladesh Archaeology, 1999-2000

Nazimuddin Ahmed, The Buildings of Khan Jahan in and Around Bagerhat, UPL, 1989.

Nazimuddin Ahmed, John Sanday, Buildings of the British Raj in Bangladesh, UPL, 1986.

Michael Harner, Archaeological-wonders/major-archaeological-sites/Cave and Cosmos: Shamanic Encounters with Another RealityPaperback, 2013.

Soper, Alexander, Evolution of Buddhist Architecture in Japan, Princeton, New Jersey: Princeton University Press, 1942.

Mizuno, Seiiehi, Asuka Buddhist Art: Horyu-ji, NY, John Weatherhill Inc. 1974.

Singh, Sheo Kumar (1982). History and Philosophy of Buddhism. Delhi: Associated Book Agency. p. 44.

Naqi, Md. Ali; Islam, Ziaul; Bhuyan, Md. Shoeb; Gomes, Catherine Daisy (1999), "The virtual reconstruction of Paharpur vihara",Khulna University Studies 1 (1): 187-204. Lars Fogelin, An Archaeological History of Indian Buddhism, Oxford Uni Press 2015. Hasibur Rahman Bilu (December 15, 2007). "Salinity and Neglect Ruin Paharpur

Terracotta". The Daily Star.

Journal of Asiatic Society of Bangladesh, Dhaka, 1998.

A Preliminary Report on Wari-Bateshwar Trial Excavation by ICSBA, Journal of Bengal Art, 5, Bangladesh, Dhaka, 2000.

H Pathan, Pratnatattvik Nidarshan- Wari-Bateshwar, Bangladesh, Dhaka, 1989. DK

Chakrabarti, Ancient Bangladesh, Bangladesh, Dhaka, 1992.

http://iceass.org/index http://press.nationalgeographic.com

http://www.thefinancialexpress-bd.com

www.thedailystar.net/book.../buddhism-bangladesh

https://en.wikipedia.org/wiki/Somapura_Mahavihara

http://shantiniketanbd.weebly.com/buddhist-heritage-site-in-bangladesh. 